\title{
Camel Trypanosomosis in Yabelo and Gomole Districts in Ethiopia: Prevalence and Associated Risk Factors Based on Parasitological Examinations
}

\author{
Oljirra Rafu' \\ Dereje Tulu $\mathbb{D}^{2}$ \\ Chaluma Negera' \\ 'Southwest Shoa Zone Livestock \\ Development and Fishery Office, Woliso, \\ Ethiopia; ${ }^{2}$ Ethiopian Institute of \\ Agricultural Research, Tepi Agricultural \\ Research Center, Tepi, Ethiopia
}

Correspondence: Dereje Tulu Ethiopian Institute of Agricultural Research, Tepi Agricultural Research Center, P.O. Box 34, Tepi, Ethiopia Email derejetulu5@gmail.com
Background: Trypanosomosis is the most prevalent disease and causes serious economic losses in Ethiopia. The disease is among the major constraint to camel production in the country. Hence, this study aimed to determine the occurrence and associated risk factors of camel trypanosomosis in the Borana zone, Ethiopia.

Methods: A cross-sectional study design was conducted from December 2018 to December 2019 using parasitological techniques in the Yabelo and Gomole districts of the Borana zone. A total of 384 camels were randomly selected and tested using wet blood film (thin) and the Giemsa-stained technique. The packed cell volume (PCV) of sampled camels was recorded using a hematocrit reader.

Results: An overall 3.91\% prevalence of camel trypanosomosis was observed in study areas. Trypanosoma-infected camel had significant $(\mathrm{P}=0.0001)$ lower mean PCV $(20.73 \pm 1.91)$ than non-infected camel $(27.07 \pm 4.35)$. The current study showed body condition of camel $(\mathrm{OR}=6.8,95 \% \mathrm{CI}: 1.44-31.83)$ and season $(\mathrm{OR}=3.1,95 \% \mathrm{CI}: 1.04-9.07)$ as risk factors for the occurrence of camel trypanosomosis. However, the sex, age, and origin (district) of camel did not affect the occurrence of camel trypanosomosis in the study areas.

Conclusion: Camel trypanosomosis impeded camel production in the study areas. Therefore, control and prevent methods considering seasonality, different ecology is necessary to design and implement. Moreover, a further study involving more sensitive molecular techniques should be conducted on camel trypanosomosis and their vectors.

Keywords: camel, risk factors, prevalence, trypanosomosis, Ethiopia

\section{Introduction}

Camel is the notable varied species of animal within the arid areas of Asia and Africa, significantly within the arid lowlands of countries like Sudan, Ethiopia, Kenya, Eritrea, and Djibouti. ${ }^{1,2}$ The camel population in the world has been estimated as about 35 million and more than $95 \%$ of these were found in developing countries. ${ }^{3}$ Ethiopia has about 2 million camels and most of them were kept in southeastern pastoral areas of the country. ${ }^{4}$ Camel production is the major livelihood of most people in the Somali, Afar, and Oromia regions. The camel is the most effective domesticated animal for changing fodder into work, transport, milk, and meat. ${ }^{5}$ Within the desert areas, camels could be important animals to the existence of individuals as the supply of food means that of transportation and most significantly its milk is used as drugs for various ailments. ${ }^{6}$ 
Camel husbandry is the primary source of living for millions of pastoralists in the arid and semiarid zone in Ethiopia and the country stands third in camel production in the world. ${ }^{3}$ Camels have a multi-purpose role within the drylands of Ethiopia like transporting grain, water, salt, and for production of milk and meat. Moreover, throughout drought conditions camels are the animal less likely affected and remain a consistent means that of transport; thus referred to as the ship of the desert. Like bovine, camel supports a range of resources (milk, meat and hide), they are a type of investment, and that they play a crucial role in pastoralist culture. They sustain the lifetime of pastoralists in those harsh environmental conditions as a result of they are the foremost economical animals in changing fodder into energy for work expendable products like meat and milk. ${ }^{7}$ Moreover, the camel is relatively less prone to several of the devastating disease; that affects different species like render pest, contagious pleuropneumonia, and foot and mouth disease; nevertheless, they are littered with several other diseases. ${ }^{8}$

Trypanosomosis is a serious pathogenic disease in camel caused by Trypanosoma evansi and it is endemic in tropical and subtropical areas. ${ }^{9}$ Camel trypanosomosis is the most prevalent disease in Ethiopia (22\%) and serious economic loss results from morbidity (30.0\%) and mortality (3.0\%) of camels in the country. ${ }^{1}$ Camel trypanosomosis or Surra is one of the major problems worldwide and it can attack camels at any age, even fetuses. In Ethiopia particularly in the Borana zone, the disease is widespread reducing thus the camel production and productivity. ${ }^{10}$ Usually, trypanosomosis in camel results in anemia, weight loss, pale mucous membranes, enlarged lymph node, loss of milk and meat, and abortion. ${ }^{11}$

The principle for the management of camel trypanosomosis was dependent on reducing the contact between camel and vectors. To effectively control camel trypanosomosis, it is crucial to know the magnitude and associated risk factors of the disease in the areas. This study helps to implement appropriate control and prevention methods. However, a little study is available that determines the occurrence and associated risk factors of Trypanosoma infection in the camel of study areas. Therefore, this study aimed to determine the magnitude and associated risk factors of camel trypanosomosis in study areas.

\section{Materials and Methods}

\section{Study Areas}

The study was carried out in two districts namely, Yabelo and Gomole districts which are located at 570 and $530 \mathrm{~km}$ from
Addis Ababa, the capital city of Ethiopia, respectively. Gomole district is situated at $40 \mathrm{~km}$ North of Yabelo district. Gomole district is located at attitude 1857 meters above sea level, $4^{\circ} 52^{\prime} \mathrm{N} 38^{\circ} 5^{\prime} \mathrm{E}$ latitude and $4.884^{\circ} \mathrm{N} 38.082^{\circ} \mathrm{E}$ longitudes while Yabelo district was located at $4^{\circ} 53^{\prime} \mathrm{N} 38^{\circ} 5^{\prime} \mathrm{E}$ latitude and $4.883^{\circ} \mathrm{N} 38.083^{\circ} \mathrm{E}$ longitudes. The areas have bimodal (two seasons) rainfall patterns with a mean annual rainfall of $558 \mathrm{~mm}$ and a mean annual temperature of $19.0^{\circ} \mathrm{C}$. January and August were the driest months with very low precipitations while April has high precipitation (average of 158 millimeters). The warmest period in the year is from March to May months, while the lowest annual minimum temperatures occur in November and January. The landscape is marked by gently sloping low lands and flood plains vegetated predominantly with grass and bushland. The general vegetation type is Acacia of savanna vegetation types dominated by bush and acacia trees. The people in the area are kept livestock as a major activity, based on the traditional pastoralist system. Borana Zone has 1,416,180 cattle, 776,870 head of sheep, 126, 2782 goats, and 23, 7250 camels. ${ }^{4}$ The pastoralist also grows some crops for their use in the valley area (Figure 1).

\section{Study Population}

The study population was dromedary camels including all sex, different age groups, and body conditions in Yabelo and Gomole districts. The study comprised a recording of age, sex, and body condition of camels in the areas to determine the prevalence of camel trypanosomosis and associated risk factors using parasitological techniques. The age of camels was categorized as less than 4 years were considered as young and above 4 years were categorized as an adult.

\section{Sampling Procedure and Sample Size Determination}

A cross-sectional study design was conducted in the Yabelo and Gomole districts of the Borana zone from December 2018 to December 2019 to determine the magnitude and associated risk factors of camel trypanosomosis. Yabelo and Gomole districts were selected purposely based on the number of camel populations. A total of eight pastoral associations (PAs) were selected randomly from the two districts (four PAs from each district). Similarly, a total of sixteen villages were selected from those PAs using the lottery method. Olla (local language Afan Oromo) is characterized by the clustering of 


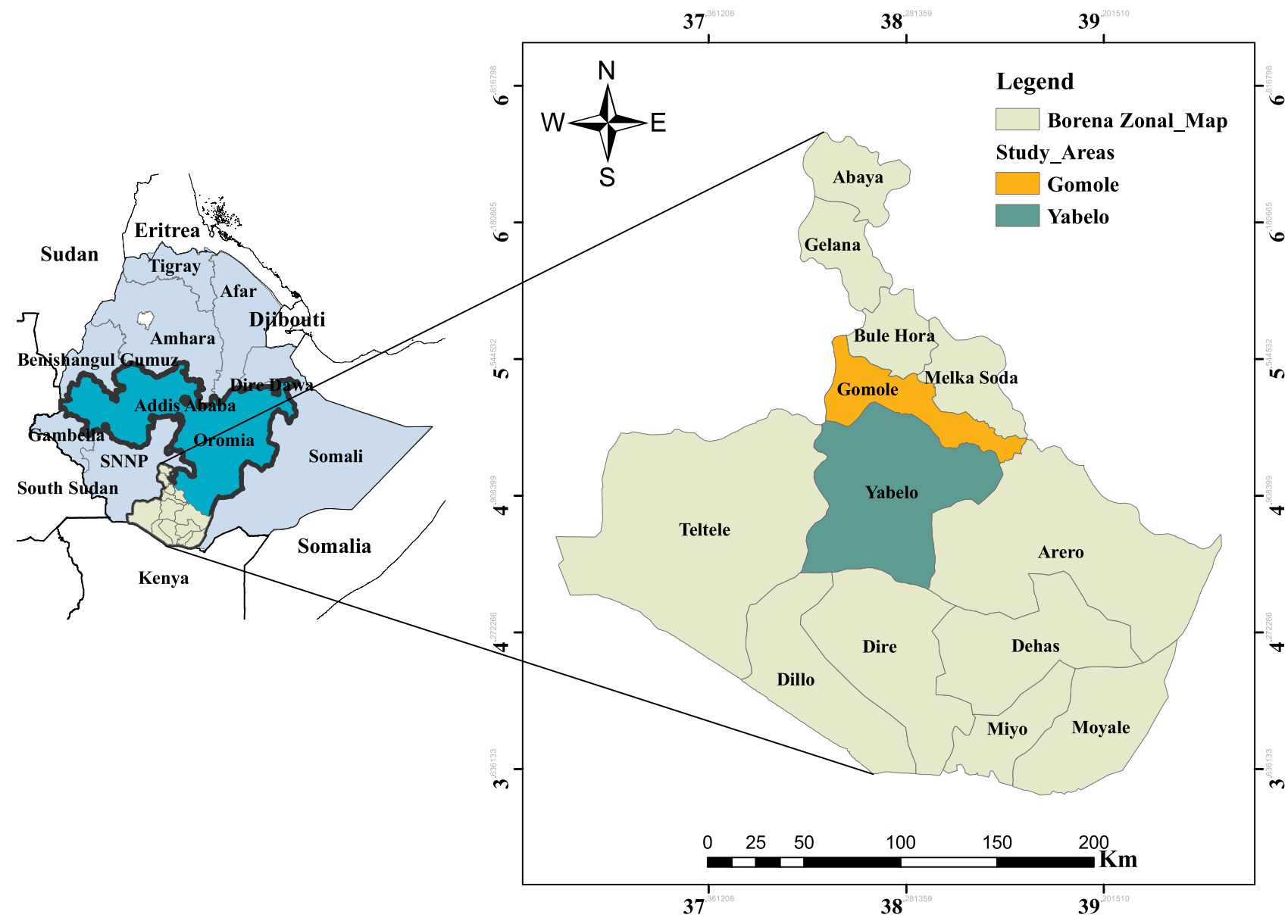

Figure I Map showing study areas (Yabelo and Gomole districts).

households with proximity houses in a pastoral campy. Each village is traditionally administered by a village chief, Abba Olla, who is an important contact person in facilitating cooperation among camel owners. Sampling frames of individual camels were obtained from $A b b a$ Olla in each respective villages. A random sampling technique was employed to select camel herds from each village. A simple random sampling was conducted to select individual camels from each herd. To estimate the sample size 95\% level of confidence (CL), 5\% desired absolute precision, and the expected prevalence of $50 \%$ was used. The sample size was determined by using the formula given by Thrusfield. ${ }^{12}$ Therefore, a total of 384 camels were needed to demonstrate the prevalence of camel trypanosomosis.

\section{Sample Collection and Laboratory Examination}

Blood samples were collected from the jugular vein of each camel with the help of a sterile lancet after disinfecting the site with $70 \%$ alcohol. Then, a blood sample was drawn by a heparinized capillary tube. The collected blood samples were centrifuged at 12,000 rpm for 5 minutes immediately in a hematocrit centrifuge and read under microhematocrit to determine package cell volume (PCV) for each sample. The camel with PCV $\leq$ $24 \%$ was assumed as anemic. ${ }^{13,14}$ The contents of the capillary tube (above $1 \mathrm{~mm}$ and below the buffy coat) were tested using the buffy coat technique to identify the Trypanosoma parasite under magnification 40x light microscope. ${ }^{15,16}$ Thin blood smears were prepared from Trypanosoma positive samples and prepared samples were dried and fixed with methanol on the day of preparation for five (5) minutes to avoid all possible deteriorations. The prepared samples were immersed in the Giemsa stain solution for 40 minutes. Then, the slides were tested using $\times 100$ magnifications with an oil immersion microscope. Trypanosoma species were identified based on the morphology of the Trypanosoma parasite like the size of the parasite, shape of the posterior end, size and position of 
the kinetoplast, and presence or absence of the flagellum following the procedure of Murray et al. ${ }^{15}$

\section{Data Management and Analysis}

The collected data during the study were entered into a Microsoft Excel spreadsheet. The prevalence of camel trypanosomiasis was computed by dividing a positive sample by a total sample collected. The confidence interval at $95 \%$ was calculated for each prevalence using Epitools online. ${ }^{17}$ The Student's $t$-test was conducted to compare the mean PCV of the infected camels with that of the non-infected camels. The presumptive risk factors of the Trypanosoma parasite in camel were tested using the logistic regression model. ${ }^{18}$ The variables were tested for multicollinearity and interaction effect using collinear matrix index and crossproduct term respectively, after univariable logistic regression analysis. Then, variables with $\mathrm{p} \leq 0.05$ in univariable analysis were entered into multivariable logistic regression analysis. The potential risk factors of camel trypanosomosis were identified using multivariable logistic regression analysis. The fitness and validity of the model were assessed by the Hosmer-Lemeshow test and ROC curve, respectively. ${ }^{18,19}$ All analyses were performed using STATA version 13.0 software. In all cases, a p-value of 0.05 and a $95 \%$ confidence interval $(\mathrm{CL})$ were used for significance.

\section{Results}

\section{Prevalence of Camel Trypanosomosis in Study Areas}

From a total of 384 camels tested, 15 were positive for Trypanozoon using wet blood film (thin) and the Giemsastained technique. The overall $3.91 \%$ of camel trypanosomosis was recorded in the areas. Trypanozoon was the Trypanosome subgenus documented in camel in the study areas. The Trypanosoma infection was higher in Gomole $(4.46 \%)$ than in Yabelo (3.30\%) districts (Table 1).

\section{Hematological Finding}

Trypanozoon infection causes anemia with a mean PCV infected camel of $20.73 \pm 1.91$ and non-infected camel $(27.07 \pm 4.35)$ with statistically significant difference $(\mathrm{P}=0.0001)$ as stated in Table 2.

\section{Univariable Logistic Regression Analysis of Risk Factors of Camel Trypanosomosis} The number of positive camels to Trypanozoon that originated from Gomole district (4.46\%) was higher than those
Table I Distribution of Camel Trypanosomosis in Gomole and Yabello Districts

\begin{tabular}{|l|l|l|l|}
\hline $\begin{array}{l}\text { Study } \\
\text { Areas }\end{array}$ & $\begin{array}{l}\text { Total Camels } \\
\text { Tested }\end{array}$ & $\begin{array}{l}\text { Prevalence } \\
\text { (\%) }\end{array}$ & 95\%; Cl \\
\hline Yabelo & 182 & $6(3.30)$ & $(0.70-5.89)$ \\
Gomole & 202 & $9(4.46)$ & $(1.61-7.30)$ \\
Overall & 384 & $15(3.91)$ & $(1.97-5.84)$ \\
\hline
\end{tabular}

Abbreviation: $\mathrm{Cl}$, confidence interval.

Table 2 Association Between Anemia and Trypanosomosis in Camels

\begin{tabular}{|l|l|l|l|l|}
\hline $\begin{array}{l}\text { Infection } \\
\text { Status }\end{array}$ & Observation & $\begin{array}{l}\text { Mean } \\
\text { PCV } \pm \text { SD }\end{array}$ & Cl; 95\% & P-value \\
\hline $\begin{array}{l}\text { Non- } \\
\text { infected }\end{array}$ & 369 & $27.07 \pm 4.35$ & & \\
\hline Infected & 15 & $20.73 \pm 1.91$ & $4.12-8.56$ & 0.0001 \\
\hline
\end{tabular}

Abbreviations: $\mathrm{PCV}$, packed cell volume; SD, standard deviation; $\mathrm{Cl}$, confidence interval.

from Yabelo district (3.30\%). However, there was no difference $(\mathrm{P}=0.340)$. Likewise, a lower prevalence of camel trypanosomosis was observed in males $(2.98 \%)$ than females $(4.63 \%)$ with a statistically insignificant difference $(\mathrm{P}=0.410)$. Even though a higher prevalence of camel trypanosomosis was noted in adults $(3.76 \%)$ than young (3.98\%), no significant difference was observed $(\mathrm{P}=0.914)$. Similarly, a higher prevalence of camel trypanosomosis was recorded in the wet season $(6.21 \%)$ than in the dry season $(2.51 \%)(\mathrm{P}=0.079)$. Nevertheless, an insignificant difference was observed between seasons in univariable logistic regression analysis $(\mathrm{P}=0.079)$. The highest prevalence of camel trypanosomosis was recorded in camel had poor body condition (7.75\%) following by medium $(2.75 \%)$ and good body $(1.37 \%)$ condition. Poor body condition camel had the highest odds $(\mathrm{OR}=6.1)$ of trypanosomosis compared to good body condition camel with statistically significant difference $(\mathrm{P}=0.022)$ as indicated in Table 3.

\section{Multivariable Logistic Regression Analysis of Risk Factors of Camel Trypanosomosis} The explanatory variables with $\mathrm{p} \leq 0.25$ in univariable analysis with no multicollinearity were further analyzed using multivariable logistic regression. No significant interactions were detected between variables. The model was fitted the data well as indicated by the Hosmer-Lemeshow test 
Table 3 Univariable Logistic Regression Analysis of Presumptive Risk Factors of Camel Trypanosomosis in Gomole and Yabello Districts

\begin{tabular}{|c|c|c|c|c|c|}
\hline Variable & Level & No Camel Tested & No Positive Camel (\%) & COR $(95 \% \mathrm{Cl})$ & p-value \\
\hline District & $\begin{array}{l}\text { Gomole } \\
\text { Yabello }\end{array}$ & $\begin{array}{l}202 \\
182\end{array}$ & $\begin{array}{l}9(4.46) \\
6(3.30)\end{array}$ & $1.4(0.48-3.92)$ & 0.340 \\
\hline Sex & $\begin{array}{l}\text { Female } \\
\text { Male }\end{array}$ & $\begin{array}{l}216 \\
168\end{array}$ & $\begin{array}{l}10(4.63) \\
5(2.98)\end{array}$ & $1.6(0.53-4.72)$ & 0.410 \\
\hline Age & $\begin{array}{l}\text { Adult } \\
\text { Young }\end{array}$ & $\begin{array}{l}251 \\
133\end{array}$ & $\begin{array}{l}10(3.98) \\
5(3.76)\end{array}$ & I.I (0.36-3.17) & 0.914 \\
\hline Body condition & $\begin{array}{l}\text { Good } \\
\text { Medium } \\
\text { Poor }\end{array}$ & $\begin{array}{l}129 \\
109 \\
146\end{array}$ & $\begin{array}{l}10(7.75) \\
3(2.75) \\
2(1.37)\end{array}$ & $\begin{array}{l}3.0(0.80-11.08) \\
6.1(1.30-28.15)\end{array}$ & $\begin{array}{l}0.105 \\
0.022\end{array}$ \\
\hline Season & $\begin{array}{l}\text { Wet } \\
\text { Dry }\end{array}$ & $\begin{array}{l}145 \\
239\end{array}$ & $\begin{array}{l}9(6.2 \mathrm{I}) \\
6(2.5 \mathrm{I})\end{array}$ & $2.6(0.90-7.38)$ & 0.079 \\
\hline
\end{tabular}

Abbreviations: $\mathrm{COR}$, crude odds ratio; $\mathrm{Cl}$, confidence interval.

$\left(\chi^{2}=1.244, p=0.871\right)$ and the area under ROC $(0.748)$ was also revealed that the model had a good predictive ability. The final multivariable logistic regression model showed that a camel with poor body condition was 6.8 times more likely to be exposed to Trypanosoma infection compared to a good body condition one. Similarly, the camel had higher odds $(\mathrm{OR}=3.1)$ of trypanosomosis in the dry season than wet season (Table 4).

\section{Discussion}

An overall $3.9 \%$ prevalence of camel trypanosomosis recorded in the present study agreed with the prevalence stated by Kassa et $\mathrm{al}^{8} 4.4 \%$ and Tadesse et $\mathrm{al}^{20} 3.5 \%$ in the Fentale district and Jijiga zone, respectively. Comparable prevalence of trypanosomosis was also documented by Gerem et $\mathrm{al}^{2}$ and Gerem and Hamid ${ }^{21} 4.5 \%$ in selected districts of the Afar region. The low prevalence observed in the current study and previous ones may be related to regular treatment and avoiding the movement of camel herds to insect challenges areas. Camel herders were aware of the seasonality and ecology of the biting flies and this could reduce the disease challenge. ${ }^{22}$ Moreover, the transmission of camel trypanosomosis was varied based on agroecology and density of biting flies. ${ }^{23}$ This might lead to the low recorded prevalence of the current study. However, the present prevalence was lower compared to the findings of Hagos et $\mathrm{al}^{24} 12.1 \%$ and Megersa ${ }^{25} 10.5 \%$ and Abdurkadir et $\mathrm{al}^{26} 10.2 \%$ in Ethiopia and prevalence of $8.3 \%$ Swai et al ${ }^{27}$ from Tanzania and $11.5 \%$ in Bhutto et $\mathrm{al}^{28}$ from Pakistan. Similarly, a higher prevalence of trypanosomosis than the present finding was also reported $21 \%$ in Ethiopia, ${ }^{29} 28 \%$ in Kenya, ${ }^{30} 68.7 \%$ in Somalia, ${ }^{31}$ and $20.6 \%$ in Egypt. ${ }^{32}$ This difference may be related to the difference in the ecosystem, distribution, and uses of the trypanocidal drug and the

Table 4 Final Multivariable Logistic Regression Model for Potential Risk Factors of Camel Trypanosomosis in Gomole and Yabello Districts

\begin{tabular}{|c|c|c|c|c|c|}
\hline Variable & Category & Number of Camels Examined & Number of Positive Camel (\%) & AOR $(95 \% \mathrm{Cl})$ & p-value \\
\hline Body condition & $\begin{array}{l}\text { Good } \\
\text { Medium } \\
\text { Poor }\end{array}$ & $\begin{array}{l}129 \\
109 \\
146\end{array}$ & $\begin{array}{l}10(7.75) \\
3(2.75) \\
2(1.37)\end{array}$ & $\begin{array}{l}3.6(0.94-13.55) \\
6.8(1.44-31.82)\end{array}$ & $\begin{array}{l}0.021 \\
0.063 \\
0.016\end{array}$ \\
\hline \multicolumn{6}{|l|}{ Season } \\
\hline & $\begin{array}{l}\text { Wet } \\
\text { Dry }\end{array}$ & $\begin{array}{l}145 \\
239\end{array}$ & $\begin{array}{l}9(6.2 I) \\
6(2.5 I)\end{array}$ & $3.1(1.05-9.07)$ & 0.041 \\
\hline
\end{tabular}

Abbreviations: $\mathrm{AOR}$, adjusted odds ratio; $\mathrm{Cl}$, confidence interval. 
seasons when the studies were conducted in which distribution of biting flies are either increase or decrease.

In the present study, Trypanozoon was the Trypanosome subgenus that causes camel trypanosomosis in the areas which is in agreement with a study done in Somalia $^{33}$ who found $5.3 \%$ of infection was due to Trypanozoon, whereas only $0.06 \%$ of the infections were due to $T$. congolense and $T$. vivax. Infection caused by Trypanosoma congolense is expected in tsetse flyinfested areas whereas T. vivax can occur anywhere as far as biting flies and parasites exist. In the Borana area, however, only biting flies exist and the occurrence of Trypanosoma congolense is less likely. Tabanus and Stomoxys genus are the most important biting flies that transmitted Trypanozoon infection in this area. ${ }^{30,34}$ Similar to this, various studies in tropical areas showed that the occurrence of Trypanozoon infection was associated with the number of biting flies. ${ }^{8,30}$ The presence of biting flies in all seasons ensures that the transmission of the parasite occurs wherever that co-existence of the reservoir and susceptible hosts. ${ }^{30}$

The present study showed that Trypanozoon infection was associated with anemia as the mean PCV of infected camel $(20.73 \pm 1.91)$ was significantly $(\mathrm{P}=0.0001)$ lower than non-infected camel (27.07 \pm 4.35$)$. The infected camel with PCV less than or equal to $24 \%$ was assumed as an anemic. ${ }^{13,14}$ Thus, Trypanozoon infection may be reduced the PCV of a diseased camel. There was also a non-infected camel with PCV $<24 \%$. This may be due to delayed recovery of anemia condition after treatment and anemia also caused by nutritional deficiencies, helminthiasis, blood parasite, and other infectious diseases. ${ }^{35}$ The infected camel with PCV $>24 \%$ was also recorded in this study. The reason for this may be some camel able to control PCV within the normal range or they were recently infected camel. The current result is consistent with previous results in the country ${ }^{36-38}$ and elsewhere, ${ }^{35,39}$ who reported that the mean PCV of trypanosomosis infected camels were significantly lower than non-infected camels.

The current study indicated that body condition was significantly associated with the occurrence of camel trypanosomosis. The odds of trypanosomosis were 6.8 times higher among camels with poor body condition than those in good body condition. This may be due to trypanosomosis results in progressive emaciation of infected camel,; however, non-infected camel under good condition have well-developed immune status that can respond to any foreign protein better than those of non-infected camel with poor body condition. ${ }^{11,40}$ This finding is in line with previous results, ${ }^{38,41}$ which stated that the occurrence of camel trypanosomosis was associated with the body condition of the camel. The season was another risk factor that has shown significantly associated with the occurrence of trypanosomosis in the camel. Camel had three times $(\mathrm{OR}=3.1)$ odds of Trypanosoma infection in the dry season than the wet season. This might be camels were overcrowded at a watering point during the dry season which facilitated the transmission of parasites among camels. ${ }^{42}$ Our result agrees with the findings of ${ }^{32,43}$ who stated that season was associated with the occurrence of Trypanosoma infection in camel.

Even though a higher prevalence of trypanosomosis was recorded in the Gomole district than in the Yabelo district, an insignificant difference was noticed between districts. This might be associated with the agroecology of the Gomole district which has several animal watering points and the presence of different size trees and shrubs along with year-round natural or artificial lakes and ponds. In agreement with the present finding, Gerem et $\mathrm{al}^{2}$ found a statistically insignificant difference between the districts. Even though a statistically insignificant difference was observed between age groups, a higher prevalence of camel trypanosomosis was recorded in young camel. This might be due to having less immunity to resist and more susceptible to the protozoan than that of the matured ones. This finding significantly differs from the previous report from Mauritania which reported that young camel $(<1$ year age) was less likely to be infected with Trypanozoon infection. ${ }^{44}$ Surra can attack camels at any age, even fetuses. ${ }^{10}$ This is because that is impossible to control of biting fly which is found everywhere and there is an equal chance of bite by flies in both adult and young. Similar to this finding, Kassa et $\mathrm{al}^{8}$ stated a higher prevalence in young than an adult in the Afar region. This result is in line with the findings of Sobhy et $\mathrm{al}^{32}$ who found a low prevalence of Trypanosoma parasite in adults than young camels.

In the current study, a higher prevalence of trypanosomosis was recorded in female than male camels,; however, the difference was statistically insignificant. This result is in line with previous findings in Pakistan and Egypt which reported a higher prevalence of trypanosomosis in female than male camels. $^{28,32}$ This also agrees with the findings of Olani et $\mathrm{al}^{45}$ and Shah et $\mathrm{al}^{46}$ who reported a higher prevalence of trypanosomosis in females than male camels. This might be due to stress during pregnancy and lactation, which could decrease 
resistance in female camels and render them more susceptible to Trypanosoma infection. In agreement with this finding, a previous study also reported as Trypanosoma infection was high during pregnancy and lactation this reduce the resistance and increase susceptibility to the disease. ${ }^{47}$

\section{Conclusion and Recommendations}

The present finding showed that trypanosomosis was a common disease in the camel herd of the most district of the study areas with a higher prevalence in the Gomole district. Camel had poor body condition was at increased risk of acquiring Trypanosoma infection. Similarly, the occurrence of trypanosomosis in the camel was influenced by season. Trypanozoon was the Trypanosome subgenus that causes camel trypanosomosis in study areas. Anemia is one of the characteristics of camel trypanosomosis. Camel trypanosomosis was an impediment to camel production in the study areas. Therefore, control and prevent methods considering seasonality, different ecology is necessary to design and implement. Moreover, a further study involving more sensitive molecular techniques should be conducted on camel trypanosomosis and its vectors.

\section{Ethical Statement}

The best practice guidelines for veterinary care were followed. All camel owners were informed as to the purpose of this study, and the verbal informed consent process was approved by Research ethics and Review committee of Hawassa University with SVM/361/2018 reference number.

\section{Acknowledgments}

We are grateful to the animal owners who participate in this study. The authors wish to thank Hawassa University for funding support and cooperation during this study. Moreover, we also thank the Borana zone livestock development and fisher office for their support without their help this work would never have been possible.

\section{Disclosure}

Funding support was proved by Hawassa University. No additional grant support was used for this study. The authors have declared no conflict of the interests for this work.

\section{References}

1. Abera Z, Usmane A, Ayana Z. Review on camel Trypanosomiasis: its epidemiology and economic importance. Acta Parasitol Glob. 2015;6 (2):117-128.
2. Gerem B, Hamid M, Assefa A. Prevalence and associated risk factors of Trypanosoma evansi in camels in Ethiopia based on parasitological examinations. Vet Med Int. 2020;2020:6. doi:10.1155/2020/6172560 Article ID 6172560.

3. FAO. Statistical Yearbook Food and Agriculture Organization of the United Nations. Italy; 2017.

4. CSA. Agricultural sample survey report on livestock and livestock characteristics, Central Statistical Agency of Ethiopia. Stat Bull. 2010;11(468):39.

5. Enwezor F, Sackey AK. Camel Trypanosomiasis; a review. Vet Arch. 2005;75:439-452.

6. Kula J, Tegegne D. Chemical composition and medicinal values of camel milk, a review. Int J Res Stud Biosci. 2016;4(4):13-25.

7. Rass N Policies and strategies to address the vulnerability of pastoralists in sub-Saharan Africa: pro-poor livestock policy, Rome Initiative Working Paper, Food and Agriculture Organization, 2006.

8. Kassa E, Tadesse HC. Prevalence of camel trypanosomosis and its vectors in Fentale district, southeast Shoa zone, Ethiopia. Vet Arch. 2011;81:611-621.

9. Eyob E, Matios L. Review on camel trypanosomiasis (surra) due to Trypanosomaevansi: epidemiology and host response. $J$ Vet Med Animal Health. 2013;5(12):334-343.

10. Omer RA, Elamin SMM, El Nahas AE, Aradaib IE. PCR for detection of Echinococcus granulosus hydatid cysts collected from camels (Camelus dromedarius). Sudan J Vet Res. 2004;43:139-143.

11. Radostits OM, Gay CC, Hinchcliff KW, Constable PD. Veterinary Medicine: A Text Book of Diseases of Cattle, Horses, Sheep, Pigs and Goats. 10th ed. New York: Saunders-Elsevier; 2007:1536-1596.

12. Thrusfield M. Veterinary Epidemiology. 3rd ed. England: Blackwell Publishing; 2005:345-543.

13. Morag GK. Hematology in Veterinary Laboratory Medicine. 2nd ed. UK: Blackwell Science; 2002.

14. Faye B, Bengoumi M. Assessment of body condition and body composition in camel by bary metric measurements. $J$ Camel Pract Res. 2006;13:67-72.

15. Murray M, Murray PK, Mclntyre WIM. An improved technique for the diagnosis of African trypanosomosis. Trans R Soc Trop Med Hyg. 1988;71(4):325-326. doi:10.1016/0035-9203(77)90110-9

16. Eisler MC, Brandt J, Bauer B, et al. Standardised tests in mice and cattle for the detection of drug resistance in tsetse-transmitted trypanosomes of African domestic cattle. Vet Parasitol. 2001;97 (3):171-183. doi:10.1016/s0304-4017(01)00415-0

17. Sergeant ESG Epitools epidemiological calculators. Ausvet Pty Ltd.; 2019. Available from: http://epitools.ausvet.com.au. Accessed November 9, 2019.

18. StataCorp. Stata Statistical Software: Release 13. USA: StataCorp LP; 2013: 13.

19. Hosmer DW, Lemeshow S, Sturdivant RX. Introduction to the Logistic Regression Model. Willey JS. New York:: Wiley Online Library; 375:2000

20. Tadesse A, Omar A, Aragaw K, Mekbib B, Sheferaw DA. Study on Camel Trypanosomiasis in Jijiga Zone, Eastern Ethiopia . $J$ Vet $A d v$. 2012;2:216-219.

21. Gerem B, Hamid M. Prevalence and associated risk factors of trypanosomiasis in camels in selected districts of Afar National Regional State, North Eastern Ethiopia. Daagu. Int J Sci Basic Appl Res 2020;2(1):89-99.

22. Demeke G Prevalence of camel trypanosomosis and factors associated with the disease occurrence in Leben district, Borena Zone, Oromiya region, Ethiopia. MSc Thesis, Addis Ababa University, Ethiopia and Free University of Berlin, Germany, 1998.

23. Luckins A. Epidemiology of surra: unanswered Questions. J Protozool Res. 1998;8:106119.

24. Hagos A, Yilkal A, Esayass T, et al. Parasitological and serological survey on trypanosomis (surra) in camels in dry and wet areas of Bale Zone, Oromyia Region, Ethiopia. Rev Med Vet (Toulouse). 2009;160 (12):569-573. 
25. Megersa B An epidemiological study of major camel diseases in the Borana lowland, Southern Ethiopia. DCG Report No.58. Dry lands Cooperation Group, Grensen 9b, 0159 Oslo, Norway, 2010.

26. Abdurkadir I, Nuradis I, Yosef D. Prevalence of camel trypanosomiasis and its associated risk factors in moyale district, Borana Zone, southern Ethiopia. BAHPA. 2015;63(3):299-312.

27. Swai ES, Moshy W, Mbise E, Kaaya J, Bwanga S. First field investigation report on the prevalence of trypanosomiasis in camels in northern Tanzania. Roavs. 2011;1:15-18.

28. Bhutto B, Gadahi J, Shah G, Dewani P, Arijo G. Field investigation on the prevalence of trypanosomiasis in camels in relation to sex, age, breeds and herd size. Pak Vet J. 2010;30:1-3.

29. Zeleke M, Bekele T. Camel herd health and productivity in eastern Ethiopia selected semi-nomadic households. Rev Elev Med Vet Pays Trop. 2001;55:213-217.

30. Njiru Z, Ole-Mapeny I, Ouma J, Ndung’U J, Olaho-Mukani W. Prevalence of trypanosomiasis in camel calves: a pilot study in Laikipia District of Kenya. Rev Elev Med Vet Pays Trop. 2001;34:183-186.

31. Hassan-Kadle AA, Ibrahim AM, Nyingilili HS, Yusuf AA, Vieira TSWJ, Vieira FC. Parasitological, serological and molecular survey of camel trypanosomiasis in Somalia. Parasit Vectors. 2019;12(1):598. doi:10.1186/s13071-019-3853-5

32. Sobhy HM, Barghash SM, Behour TS, Razin EA. Seasonal fluctuation of trypanosomiasis in camels in North-West Egypt and effect of age, sex, location, health status and vector abundance on the prevalence. Beni-Seuf Univ J Basic Appl Sci 2017;6(1):64-68. doi:10.1016/j.bjbas.2017.01.003

33. Dirie MF, Wallbanks KR, Aden AA, Bornstein S, Ibrahim MD. Camel trypanosomiasis and its vectors in Somalia. Vet Parasitol. 1989;32(4):285-291. doi:10.1016/0304-4017(89)90039-3

34. Mahmoud MM, Gray AR. Trypanosomiasis due toTrypanosoma evansi (steel, 1885) balbiani, 1888. A review of recent research. Trop Anim Health Prod. 1980;12(1):35-47. doi:10.1007/BF02242629

35. Boushakia D, Adel A, Dia ML, et al. Epidemiological investigations on Trypanosoma evansi infection in dromedary camels in the South of Algeria. Heliyon. 2019;5(7):e02086. doi:10.1016/j.heliyon.2019. e02086

36. Ibrahim AM, Ismail AA, Majid AA, Sidig HS, Osman ME, Rahman AH. Packed cell volume as an indicator of camel trypanosomosis in the Sudan. Animal Prod Res Adv. 2010;6(4):247-251.
37. Birhanu H, Fikru R, Said M, et al. Epidemiology of Trypanosoma evansi and Trypanosoma vivax in domestic animals from selected districts of Tigray and Afar regions, Northern Ethiopia. Parasit Vectors. 2015;8(1):212. doi:10.1186/s13071-015-0818-1

38. Fikru R, Andualem Y, Getachew T, et al. Trypanosome infection in dromedary camels in Eastern Ethiopia: prevalence, relative performance of diagnostic tools and host related risk factors. Vet Parasitol. 2015;211(3-4):175-181. doi:10.1016/j.vetpar.2015.04.008

39. Mossaad E, Salim B, Suganuma K, et al. Trypanosoma vivax is the second leading cause of camel trypanosomosis in Sudan after Trypanosoma evansi. Parasit Vectors. 2017;10(1):176. doi:10.1186/ s13071-017-2117-5

40. Taylor AM, Coop LR, Wall LR. Veterinary Parasitology. 3rd ed. UK: Blackwell publishing; 2007:44-102.

41. Mohamed MA, Mohamoud AA, Adow HI, Bitrus AA. Seroprevalence of Trypanosoma evansi in dromedary camels from selected dairy farms in Benadir, Somalia. Adv Animal Vet Sci. 2020;8 (3):333-338. doi:10.17582/journal.aavs/2020/8.3.333.338

42. Elamin E, El Bashir M, Saeed E. Prevalence and infection pattern of Trypanosoma evansi in camels in mid-eastern Sudan. Trop Anim Health Prod. 1998;30(2):107-114. doi:10.1023/A:1005047801206

43. Ngaira JM, Bett B, Karanja SM. Animal-level risk factors for Trypanosoma evansi; infection in camels in eastern and central parts of Kenya. Onderstepoort J Vet Res. 2002;69:263-271.

44. Jacquiet $\mathrm{P}, \mathrm{Dia} \mathrm{M}, \mathrm{Cheikh} \mathrm{D}$, Thiam $\mathrm{A}$. La trypanosomose cameline à Trypanosoma evansi (Steel 1885), Balbiani 1888, en République islamique de Mauritanie: résultats d'enquêtes dans le Trarza. Rev Elev Med Vet Pays Trop. 1994;47(1):59-62. doi:10.19182/remvt.9133

45. Olani A, Habtamu Y, Wegayehu T, Anberber M. Prevalence of camel trypanosomosis (surra) and associated risk factors in Borena zone, southern Ethiopia. Parasitol Res. 2016;115(3):1141-1147. doi:10.1007/s00436-015-4845-9

46. Shah SR, Phulan MS, Memon MA, Rind R, Bhatti WM. Trypanosomes infection in camels. Pak Vet J. 2004;24:209-210.

47. Barghash SM, El-Naga TR, El-Sherbeny EA, Darwish AM. Prevalence of Trypanosoma evansi in Maghrabi camels (Camelus dromedarius) in Northern-West Coast, Egypt using molecular and parasitological methods. Acta Parasitol Glob. 2014;5:125-132.

\section{Publish your work in this journal}

Veterinary Medicine: Research and Reports is an international, peerreviewed, open access journal publishing original research, case reports, editorials, reviews and commentaries on all areas of veterinary medicine. The manuscript management system is completely online and includes a very quick and fair peer-review system. Visit http://www.dovepress.com/testimonials.php to read real quotes from published authors. 